\title{
Sacral schwannoma with intraosseous extension
}

\author{
Carlos Dias Silva, ${ }^{1,2}$ José Eduardo Mateus, ${ }^{1,2}$ Joana Oliveira Silva, ${ }^{1}$ Teresa Vaio ${ }^{1,2}$
}

${ }^{1}$ Internal Medicine Department, Centro Hospitalar e Universitario de Coimbra EPE, Coimbra, Portugal

${ }^{2}$ Faculdade de Medicina, Universidade de Coimbra, Coimbra, Portugal

Correspondence to Dr Carlos Dias Silva, cdiasdasilva13@gmail.com

Accepted 18 December 2018

A Check for updates

(c) BMJ Publishing Group Limited 2019. No commercial re-use. See rights and permissions. Published by BMJ.

To cite: Silva CD, Mateus JE, Silva JO, et al. BMJ Case Rep 2019;12:e227095. doi:10.1136/bcr-2018227095

\section{DESCRIPTION}

A 22-year-old man presented with a 24-hour history of bilateral lumbar pain, abdominal pain, nausea, fever and difficulty walking. Two months before he had similar complaints. The patient had no significant medical history except for a car accident 6 years before with left lower limb trauma without fracture.

Physical examination revealed fever $\left(38.8^{\circ} \mathrm{C}\right)$ and inferior abdominal and lower back pain on percussion. Laboratory data showed normal leucocytes count $(9.3 \mathrm{~g} / \mathrm{dL}, 91 \%$ neutrophils), elevated C reactive protein $(4.85 \mathrm{mg} / \mathrm{dL})$ and hyperamylasaemia (245 U/L). Abdominal ultrasound showed minimal left ureteropelvic dilatation without obstruction. The plain pelvic radiograph showed a lesion next to left sacral wing (figure 1A). After a careful look at the radiograph performed 6 years before, at the time of the accident, a mass lesion was already apparent in the same locus, raising the suspicion for a slow-growing tumour. Positron emission tomography/CT scan revealed a large osteolytic lesion with soft tissue component (figure 1B) measuring $7.0 \times 5.7 \times 6.0 \mathrm{~cm}$ and causing scalloping at the surrounding bone in the left sacral wing with heterogeneous ${ }^{18} \mathrm{~F}$-labelled fluoro-2- deoxyglucose uptake, as well as a mesenteric ganglion. Skeletal scintigraphy demonstrated a cold lesion.

Considering the morphology of the lesion, the following differential diagnoses were proposed: chordoma, giant cell tumour of bone, osteoblastoma, chondroblastoma, osteosarcoma, schwannoma among others. However, given the remaining characteristics, a slow-growing benign lesion would be more likely, and therefore a

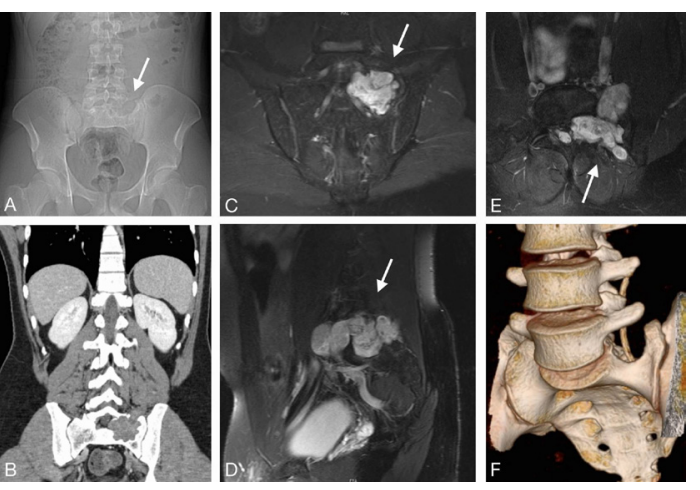

Figure 1 (A) Pelvic radiograph at the time of presentation. (B) Soft tissue mass of the left sacral wing on abdominopelvic CT scan (coronal view). (C-E) T2weighted pelvic MRI showing a high signal intensity sacral lesion (coronal, sagittal and transversal view respectively). (F) Postoperative 3D pelvic CT scan showing complete lesion removal.
CT-guided biopsy was decided in a multidisciplinary meeting, contrary to the approach in the majority of suspected malignant neoplasms. The biopsy showed a spindle cell neoplasm with low cytological aggressiveness and schwannoma differentiation. A pelvic MRI with gadolinium was then performed, demonstrating suspicious features as evidenced by the extraosseous enhancing soft tissue component (figure 1C-E).

Local complete excision of the tumour was achieved via laparotomy using the posterior-left paravertebral approach, in the prone position. Left foraminotomy L5-S1 and partial osteotomy of the posterior wall of sacrum were made to remove the tumour piece by piece (figure 1F). S1 and L5 roots were identified and preserved, avoiding possible sensorimotor deficits. Anatomopathological findings were consistent with WHO grade I schwannoma. There were no signs of recurrence at 2 years' follow-up.

Schwannomas are relatively uncommon tumours derived from Schwann cells that cover myelinated nerve fibres. ${ }^{12}$ Most schwannomas are idiopathic but may also occur in association with genetic syndromes. Sporadic schwannomas affect mostly women between 20 and 50 years. These tumours are usually found in the head, neck and extremities. Intraosseous schwannomas are extremely rare $(0.3 \%-5 \%$ of all cases $),{ }^{13}$ most of them located in the retroperitoneal space. Retroperitoneal schwannomas eroding vertebrae or the sacrum are even more atypical and specific literature is scarce. Schwannomas are typically benign (with a few exceptions) but often cannot be distinguished from malignant peripheral nerve sheath tumours due to similar imaging findings. Complete excision is the treatment of choice but is frequently difficult to achieve because of its localisation and considering the importance to avoid inadvertent injury to adjacent nerves and vessels. ${ }^{1-3}$

\section{Learning points}

- Although generally benign, schwannomas may be difficult to distinguish from malignant peripheral nerve sheath tumours but also other tumours (eg, osteosarcoma) solely by imaging techniques, often leading to a lesion biopsy.

- Intraosseous schwannoma is extremely rare and can pose a treatment challenge if located retroperitoneally because of a more difficult surgical approach.

Contributors All of the authors certify that they will take public responsibility for the contents, have contributed substantially to the drafting and have approved the final version. CDS and JEM: acquired data, reported the case and designed the paper. JOS: 


\section{Images in...}

reviewed the literature about this topic, and with TV discussed the planning and corrected the case report article.

Funding The authors have not declared a specific grant for this research from any funding agency in the public, commercial or not-for-profit sectors.

Disclaimer The work has not been published and is not under consideration elsewhere and does not duplicate or overlap other published work.

Competing interests None declared.

Patient consent Obtained.
Provenance and peer review Not commissioned; externally peer reviewed.

\section{REFERENCES}

1 Sakalauskaite M, Stanaitis J, Cepkus S, et al. Retroperitoneal giant schwannoma eroding lumbal vertebra: a case report with a literature review. Open Med 2008;3:233-44.

2 Singh V, Kapoor R. Atypical presentations of benign retroperitoneal schwannoma: report of three cases with review of literature. Int Urol Nephrol 2005;37:547-9.

3 Mutlu A, Tutar S, Ozturk E, et al. Intraosseous schwannoma of the sacrum. Spine J 2016;16:e407-8.

Copyright 2018 BMJ Publishing Group. All rights reserved. For permission to reuse any of this content visit

https://www.bmj.com/company/products-services/rights-and-licensing/permissions/

BMJ Case Report Fellows may re-use this article for personal use and teaching without any further permission.

Become a Fellow of BMJ Case Reports today and you can:

- Submit as many cases as you like

Enjoy fast sympathetic peer review and rapid publication of accepted articles

- Access all the published articles

Re-use any of the published material for personal use and teaching without further permission

For information on Institutional Fellowships contact consortiasales@bmjgroup.com

Visit casereports.bmj.com for more articles like this and to become a Fellow 